\title{
Pengaruh Inovasi dan Kreativitas Terhadap Kepuasan Konsumen pada UKM Dina Kelurahan Ntobo
}

\author{
Yeni Afriyani \\ yeniafriyani17.stiebima@gmail.com \\ Sekolah Tinggi Ilmu Ekonomi (STIE) Bima \\ Muhajirin \\ jirin.stiebima@gmail.com \\ Sekolah Tinggi Ilmu Ekonomi (STIE) Bima
}

\begin{abstract}
This study aims to determine the effect of innovation and creativity on consumer satisfaction at UKM Dina, Ntobo Village. The approach used in this research is to use an associative approach. The population in this study amounted to 100 people with a sample of 100 consumers. The sampling technique used was incidental sampling, the data collection techniques used were observation, questionnaires, and literature study. Data analysis techniques used are validity and reliability tests, classical assumption tests, multiple linear regression analysis, correlation coefficient, determination coefficient, $T$ test, and $F$ test by using the Statistical Product and Service Solution (SPSS) version 20 program. It shows that innovation has a partial effect on consumer satisfaction at UKM Dina, Ntobo Village, creativity has partial effect on consumer satisfaction at UKM Dina, Ntobo Village, innovation and creativity simultaneously affects consumer satisfaction at UKM Dina, Ntobo Village.
\end{abstract}

Keywords : creativity, customer satisfaction, innovation

\section{Pendahuluan}

\subsection{Latar Belakang}

Usaha kecil adalah usaha ekonomi produktif yang berdiri sendiri, yang dilakukan oleh perorangan atau badan usaha yang bukan merupakan anak perusahaan atau bukan cabang perusahaan yang dimiliki, dikuasai, atau menjadi bagian baik langsung maupun tidak langsung dari usaha menengah atau usaha besar yang memenuhi kriteria usaha kecil sebagaimana dimaksud dalam undang-undang UMKM (Undang-undang nomor 20 tahun 2008 tentang usaha mikro kecil dan menengah). Usaha kecil menengah (UKM) memiliki peran yang cukup kuat dalam pembangunan ekonomi Indonesia dan dianggap sebagai motor penggerak perekonomian suatu daerah. Hal ini ditunjukkan ketika adanya krisis perekonomian tahun 1998 dan usaha kecil merupakan kelompok yang paling bertahan disaat tidak sedikit usaha-usaha besar mengalami gulung tikar (Aditi dan Hermansyur, 2018).

Salah satu langkah dalam mendukung tercapainya pembangunan nasional adalah pemberdayaan masyarakat melalui usaha kecil dan menengah (UKM). Pemberdayaan UKM di tengah arus globalisasi dan tingginya persaingan membuat UKM harus mampu menghadapi tantangan global seperti meningkatkan kreativitas produk dan jasa, pengembangan sumber daya manusia dan teknologi, serta perluasan area pemasaran. Selain itu, perubahan selera masyarakat yang tidak dapat diprediksi membuat para pelaku usaha UKM dituntut untuk memiliki kreativitas agar dapat terus menciptakan karya-karya yang bernilai dan memiliki identitas (Sudaryanto dan Wijayanti, 2014).

Inovasi merupakan kemampuan untuk menerapkan kreativitas dalam rangka pemecahan masalah dan dapat menemukan peluang untuk mengembangkan produk yang sudah ada. Seorang pemilik usaha dituntut untuk selalu berinovasi dalam meningkatkan kualitas dari produk yang dihasilkan. hal ini tidak terlepas dari keinginan kunsumen yang selalu berubahubah. Inovasi produk adalah salah satu faktor yang paling diandalkan oleh seorang pemasar dalam memasarkan suatu produk. Inovasi akan meningkatkan nilai tambah suatu produk, 
inovasi akan menciptakan suatu produk baru yang dapat memberikan solusi yang lebih baik bagi pemecahan masalah yang dihadapi konsumen.

Kreativitas dilandasi oleh cara berpikir yang maju, penuh dengan gagasan-gagasan baru yang berbeda dengan produk-produk yang telah ada di pasar. Kreativitas merupakan inisiatif terhadap suatu tugas yang lebih bersifat heuristic, yaitu sesuatu yang merupakan pedoman, petunjuk atau panduan yang tidak lengkap yang akan menuntun seseorang untuk mengerti, mempelajari atau menemukan sesuatu yang baru. kreativitas memiliki kemampuan untuk mengembangkan ide baru dari ide yang telah dimiliki, dan kemudian menggabungkan ide-ide baru yang dimiliki tersebut untuk membentuk inovasi yang bermanfaat, begitu seterusnya sampai proses tersebut berlanjut (Hidiyati 2011).

Inovasi dan kreativitas merupakan hal yang sangat penting dalam suatu bisnis dan juga berpengaruh terhadap minat beli para konsumen. Dengan inovasi yang baik dan mengikuti perkembangan jaman, konsumen akan merasa sangat puas dengan berbelanja ditempat tersebut sehingga penjualan juga akan meningkat. Namun, apabila suatu usaha tidak melakukan inovasi, maka konsumen akan beralih ke pesaing. Kemudian apabila inovasi yang dilakukan kurang menarik, maka konsumen akan merasa jenuh dengan produk tersebut dan mulai mencari penjual lain, sehingga menurunkan penjualan serta omset suatu bisnis.

Kepuasan konsumen berhubungan erat dengan kualitas produk dan jasa yang dihasilkan oleh suatu perusahaan ataupun usaha, di mana tingkat kualitas yang tinggi akan menghasilkan kepuasan konsumen yang lebih tinggi juga. Kepuasan konsumen ialah terciptanya perasaan gembira atau kecewa yang disebabkan oleh perbandingan antara hasil produk dengan ekspetasi yang konsumen harapkan. Konsumen yang tidak puas terhadap barang atau jasa yang dikonsumsinya akan mencari perusahaan lain yang mampu menyediakan kebutuhannya.

UKM Dina merupakan salah satu UKM Tenun yang ada di Kota Bima yang bertempat di Jl. Lintas Kelurahan Ntobo Kota Bima. Keberadaannya pun sudah diakui oleh pemerintah pusat melalui penghargaan OVOP INDONESIA (Produk OVOP bintang 3) karena mampu menciptakan produk unggul dan bersaing yang ada di Kota Bima. Berdasarkan observasi yang dilakukan peneliti, masalah-masalah yang timbul pada UKM Dina Kelurahan Ntobo yaitu masih sedikitnya motif yang dipakai atau masih menggunakan motif yang lama, perpaduan warna benang yang digunakan masih kurang menarik, terbatasnya keterampilan dalam menciptakan produkproduk baru sehingga produk yang diciptakan masih yang itu-itu saja, serta perubahan selera konsumen yang berubah-ubah sehingga memaksa pelaku UKM kain tenun harus inovatif dan kreativ dalam mempertahankan kepuasan dan loyalitas konsumen

\section{Tinjauan Pustaka}

\subsection{Inovasi}

Inovasi adalah alat spesifik bagi pelaku usaha untuk memanfaatkan perubahan sebagai peluang bisnis atau jasa yang berbeda. Nilai tambah inovasi produk kepada pelanggan ditentukan dengan produk-produk yang ada di pasaran terlepas dari apakah produk tersebut di produksi oleh produsen atau pesaing lain (Anselmsson \& Johansson, 2009)

Sutarno (2012) menerangkan bahwa inovasi merupakan transformasi pengetahuan kepada produk, proses serta jasa baru, kegiatan memanfaatkan suatu yang baru. Sedangkan Setiadi (2015) menjelaskan suatu inovasi didefinisikan bagaikan inspirasi atau produk apapun yang dialami oleh calon adopter selaku suatu yang baru. Inovasi merupakan perbaikan produkproduk yang sudah ada menjadi lebih baik dengan pemikiran yang berbeda dari yang lain. Kotler (2011) menjelaskan inovasi yang dilakukan pada produk bukan berupa produk baru saja akan tetapi menciptakan peluang usaha dan metode dalam menjalankan juga harus baru, sehingga dapat menciptakan nilai yang tinggi dimata konsumen, maka perusahaan tersebut bisa memenangkan pasar.

Indikator-indikator inovasi menurut Zimmerer dan Scarborough (2008) terdiri dari :

a. Perubahan desain, yaitu tingkat merubah-ubah desain produk yang sudah ada menjadi berbeda.

b. Inovasi Teknis, yaitu tingkat memperhatikan proses perusahaan dalam mengasilkan produk yang bertujuan untuk memuaskan tuntutan pelanggan. 
c. Pengembangan produk, yaitu tingkat mengembangkan produk untuk menarik minat beli pelanggan.

\subsection{Kreativitas}

Hardvar's Theodore Levitt dalam Suryana (2013) mengemukakan bahwa kreativitas adalah kemampuan seseorang dalam mengembangkan ide-ide baru dan mengemukakan caracara baru dalam memecahkan persoalan dan dalam menghadapi peluang. Zimmerer dalam Suryana (2010) mendefinisikan bahwa kreativitas merupakan kemampuan dalam menuangkan ide atau gagasan melalui proses berpikir kretaif untuk menciptakan sesuatu. Sedangkan Hadiyati (2011) mengatakan bahwa : "Kreativitas adalah inisiatif terhadap suatu produk atau proses yang bermanfaat, benar, tepat dan bernilai terhadap suatu suatu tugas yang bersifat heuristic yaitu sesuatu yang merupakan pedoman, petunjuk, atau panduan yang tidak lengkap yang akan menuntun kita untuk mengerti, mempelajari atau menemukan sesuatu hal yang baru. Indikator-indikator kreativitas dalam Suryana (2008) sebagai berikut:

a. Ingin tahu, yaitu Tingkat keingin tahuan membantu menumbuhkan ide-ide yang baru.

b. Optimis, yaitu tingkat keoptimisan dalam menciptakan produk baru.

c. Flexibel, yaitu Tingkat sikap flexibel yang dapat membantu mengembangkan produk baru.

d. Mencari solusi, yaitu tingkat mencari solusi untuk menghadapi masalah yang sedang di hadapi oleh perusahaan.

e. Suka berimajinasi, yaitu tingkat suka berimajinasi untuk menciptakan sebuah produk yang berbeda.

\subsection{Kepuasan Konsumen}

Kepuasan konsumen menurut Kotler (2005), "kepuasan konsumen adalah perasaan senang atau kecewa seseorang yang muncul setelah membandingkan kinerja (hasil) produk yang dipikirkan terhadap kerja (atau hasil) yang diharapkan". Jika kinerja berada di bawah harapan, pelanggan tidak puas. Jika kinerja melebihi harapan, pelanggan amat puas atau senang.

Kepuasan konsumen adalah sejauh mana manfaat sebuah produk dirasakan (perceived) sesuai dengan apa yang diharapkan pelanggan (Amir, 2005). Sedangkan Kotler dan Keller (2012) mendefinisikan kepuasan konsumen merupakan merupakan tingkat perasaan seseorang sesudah menyamakan kinerja atau hasil yang dia rasakan dibanding dengan harapannya. Robbert, Patrick dan James (2012) dalam Wariki, Mananeke \& Tawas (2015) mengemukakan bahwa kepuasan ialah aspek utama untuk banyak pelanggan buat senantiasa setia. Hingga bisa didefinisikan kalau kepuasan konsumen merupakan perasaan yang timbul dari konsumen kala dia sudah merasakan dampak yang dia terima pasca keputusan pembelian. Kepuasan konsumen merupakan evaluasi purna beli dimana alternatif yang dipilih sekurang-kurangnya sama atau melampaui harapan konsumen, sedangkan ketidakpuasan timbul apabila hasil tidak memenuhi harapan (Tjiptono 2013).

Indikator-indikator kepuasan konsumen menurut Irawan (2008) yaitu :

a. Kenyamanan yang dirasakan pelanggan pada saat pelayanan di berikan

b. Minat untuk membeli ulang produk

c. Perasaan puas atas produk yang telah dibeli

\subsection{Pengaruh Inovasi Terhadap Kepuasan Konsumen}

Produk yang berinovasi dapat diartikan dimana perusahaan bekerja untuk menemukan jalan keluar untuk kemajuan dan perkembangan produk sehingga dapat mendiferensiasikan produk dan dapat membangun pengelolaan sebuah produk yang dipasarkan dengan tujuan meningkatkan kepuasan konsumen. Hasil penelitian Sukarmen (2015) membuktikan bahwa inovasi inovasi berpengaruh signifikan secara parsial terhadap kepuasan konsumen. Berdasarkan uraian di atas, maka hipotesis yang diajukan dalam penelitian ini adalah :

H1 : Inovasi berpengaruh signifikan terhadap kepuasan konsumen pada UKM Dina Kelurahan Ntobo 


\subsection{Pengaruh Kreativitas Terhadap Kepuasan Konsumen}

Kreatifitas produk merupakan hasil ide dari perusahaan yang memberikan perbedaan dari perusahaan yang lain dan lebih mempunyai tingkatan yang tinggi sehingga dapat memberikan nilai yang belum ditemukan konsumen pada perusahaan yang lain sehingga tercapainya tingkat kepuasan konsumen diharapkan perusahaan (Tjiptono, 2015). Inovasi produk berkaitan erat dengan kepuasan konsumen, yang memberikan penilaian atas suatu produk adalah konsumen pemakai itu sendiri. Hasil penelitian yang dilakukan oleh Munthe (2019) menyatakan bahwa Kreativitas berpengaruh signifikan secara parsial terhadap kepuasan konsumen. Berdasarkan hal tersebut, maka hipotesis yang diajukan dalam penelitian ini adalah :

H2 :Kreativitas berpengaruh signifikan terhadap kepuasan konsumenpada UKM Dina Kelurahan Ntobo

\subsection{Pengaruh Inovasi Dan Kreativitas Terhadap Kepuasan Konsumen}

Kreativitas serta inovasi diartikan sebagai hal yang mendasar dalam sebuah usaha karena dapat mempengaruhi minat beli dengan inovasi yang yang baik sesuai dengan kemajuan zaman, perusahaan akan terus mendapatkan laba dari penjualan yang terus meningkat, sebaliknya jika produk tanpa inivasi dan kreativitas, maka konsumen akan beralih ke pesaing sehingga volume penjualan akan menurun (Aditi \& Hermansyur, 2018). Selanjutnya dikatakan bahwa inovasi dan kreativitas berpengaruh signifikan secara simultan terhadap kepuasan konsumen. Berdasarkan uraian di atas, maka hipotesis yang diajukan dalam penelitian ini adalah

H3 : Inovasi dan Kreativitas berpengaruh signifikan terhadap kepuasan konsumen pada UKM Dina Kelurahan Ntobo

\section{Metodologi}

\subsection{Jenis Penelitian}

Jenis penelitian ini adalah penelitian asosiatif. Penelitian asosiatif merupakan suatu pernyataan yang menunjukkan dugaan tentang hubungan antara dua variable (Sugiyono, 2012). Penelitian asosiatif dalam penelitian ini digunakan untuk mengerahui pengaruh inovasi dan kreativitas terhadap kepuasan konsumen pada UKM Dina Kelurahan Ntobo.

\subsection{Populasi, Sampel dan Sampling Penelitian}

\subsubsection{Populasi}

Menurut Sugiyono (2016), populasi adalah wilayah generalisasi yamg terdiri atas obyek/subyek yang mempunyai kualitas dan karakteristik tertentu yang ditetapkan oleh peneliti untuk dipelajari kemudian ditarik kesimpulannya. Adapun populasi dalam penelitian ini yaitu seluruh pengunjung yang pernah membeli produk pada UKM Dina Kelurahan Ntobo.

\subsubsection{Sampel}

Menurut Sugiyono (2016), sampel adalah bagian dari jumlah karakteristik yang dimiliki oleh populasi tersebut. Sampel yang akan digunakan dalam penelitian ini ditentukan dengan menggunakan rumus Ferninand (2014), yaitu Jumlah sampel = Jumlah Indikator x 5 sampai 10. Karena dalam penelitian ini terdapat 11 indikator, maka jumlah sampel yang digunakan adalah : Sampel minimum $=11 \times 9=99$, dibulatkan menjadi 100 responden.

\subsubsection{Teknik sampling}

Teknik sampling yang digunakan oleh peneliti dalam penelitian ini adalah sampling accidental, yaitu teknik penentuan sampel berdasarkan kebetulan, yaitu siapa saja pasien yang secara kebetulan bertemu dengan peneliti, dapat digunakan sebagai sampel, bila dipandang orang yang kebetulan ditemui itu cocok sebagai sumber data (Sugiyono, 2016). 


\subsection{Instrumen Penelitian dan Teknik Pengumpulan Data}

\subsubsection{Instrumen Penelitian}

Untuk mengukur hubungan antara variabel bebas dan terikat maka digunakan kuesioner yang bersifat tertutup di mana responden diberi alternatif pilihan jawaban pada setiap pernyataan. Kuisioner dibagikan pada sejumlah responden, dan seluruh variabel akan diukur menggunakan skala likert sebagai berikut :

a. Jawaban sangat setuju diberi bobot 5 (lima)

b. Jawaban setuju diberi bobot 4 (empat)

c. Jawaban netral diberi bobot 3 (tiga)

d. Jawaban tidak setuju diberi bobot 2 (dua)

e. Jawaban sangat tidak setuju diberi bobot 1 (satu)

\subsubsection{Teknik Pengumpulan Data}

a. Observasi

Menurut Sugiyono (2016), observasi adalah suatu metode atau cara untuk menganalisis dan melakukan pencatatan yang dilakukan secara sistematis, tidak hanya terbatas dari orang, tetapi juga objek-objek alam yang lain. Dalam hal ini, peneliti melakukan observasi kepada beberapa pengunjung UKM Dina Kelurahan Ntobo.

b. Angket (Kuesioner)

Menurut Sugiyono (2016), kuesioner merupakan teknik pengumpulan data yang dilakukan dengan cara memberi seperangkat pertanyaan atau pernyataan tertulis kepada responden untuk dijawabnya.

c. Studi pustaka

Menurut Sugiyono (2016), studi pustaka berkaitan dengan kajian teoritis dan referensi lain yang berakitan dengan nilai, budaya dan norma yang berkembang pada situasi sosial yang diteliti, selain itu studi pustaka sangat penting dalam melakukan penelitian, hal ini di karenakan penelitian tidak akan lepas dari literatur-literatur ilmiah.

d. Lokasi penelitian

Adapun lokasi dari penelitian ini yaitu pada UKM Dina Kelurahan Ntobo, Jl. Lintas Ntobo, Raba Kota Bima Nusa Tenggara Barat.

\subsection{Teknik Analisis Data}

\subsubsection{Uji Validitas dan Uji Reabilitas}

a. Uji validitas

Menurut Sugiyono (2016) menunjukkan derajat ketepatan antara data yang sesungguhnya terjadi pada objek dengan data yang dikumpulkan oleh peneliti untuk mencari validitas sebuah item, kita mengkolerasikan skor item dengan total-total item tersebut 0,195 (standar realisasi R tabel).

b. Uji Reliabilitas

Menurut Ghozali (2013), reliabilitas berhubungan dengan kepercayaan masyarakat. Reabilitas merupakan alat untuk mengukur suatu daftar pertanyaan koisioner yang merupakan indikator dari variabel-variabel yang diteliti. Uji reliabilitas dilakukan terhadap item pertanyaan yang dinyatakan reabel 0,600 (standar reabilitas).

\subsubsection{Uji Asumsi Klasik}

a. Uji Normalitas

Menurut Ghozali (2013), tujuan dari uji normalitas adalah untuk mengetahui apakah masung-masing variabel berdistribusi normal atau tidak.

b. Uji Heteroskesdastisitas

Menurut Ghozali (2013), uji heteroskesdastisitas bertujuan untuk menguji apakah apakah dalam model regresi terjadi ketidaksamaan varians dari residual satu pengamatan ke pengamatan lain tetap, maka disebut heteroskesdastisitas dan jika berbeda disebut tidak heteroskesdastisitas. 
c. Uji Multikolonieritas

Multikoliniearitis merupakan suatu situasi dimana beberapa atau semua variabel berkorelasi kuat.Pengujian terhadap multikolinearitas pada penelitian ini dilakukan dengan nilai Variance Inflation Factor (VIF). Bila VIF diatas 10 maka dikatakan tidak terjadi kolinearitas yang berarti multiolinearitas terpenuhi.

d. Uji Autokorelasi

Menurut Ghozali (2013) uji autokorelasi bertujuan untuk menguji apakah dalam model regresi ada korelasi antara kesalahan penggganggu pada periode t-1 (sebelumnya).

\subsubsection{Regresi Linear Berganda}

Analisis yang digunakan dalam penelitian ini adalah analisis linear berganda yaitu model regresi untuk menganalisis lebin dari satu variabel independen.

a. Uji Koefisien Korelasi

Korelasi berganda adalah suatu kondisi yang bermaksud untuk melihat hubungan antara 3 atau lebih variabel (dua atau lebih variabel dependen dan satu variabel independen).

b. Uji Koefisien Determinasi

Koefisien determinasi $\left(\mathrm{R}^{2}\right)$ digunakan untuk mengetahui presentasi variabel independen secara bersama sama dapat menjelaskan variabel dependen. Nilai koefisien determinasi adalah antara nol dan satu. Jika koefisien determinasi $\left(\mathrm{R}^{2}\right)=1$, artinya variabel independent memberikan semua informasi yang dibutuhkan untuk memprediksi variasi variabel dependen. Jika koefisien determinasi $\left(\mathrm{R}^{2}\right)=0$, artinya variabel independen tidak mampu menjelaskan variasi variabel dependen dengan menggunakan bantuan SPSS.

c. Uji Parsial (uji t)

Uji parsial dengan $t$ test ini bertujuan untuk mengetahui besarnya pengaruh masingmasing variabel independent secara individu (parsial) terhadap variabel dependen. Pengujian $t$ dilakukan dengan membandingkan t hitung dengan $t$ tabel. Jika $t$ hitung lebih besar dari $t$ tabel pada tingkat kepercayaan $95 \%$ atau ( $p$-value $<0,05$ ), maka Ha diterima, yang artinya variabel independen yang diuji secara persial mempunyai pengaruh terhadap variabel dependent.

d. Uji Simultan (Uji F)

Uji simultan dengan F pada dasarnya bertujuan untuk mengetahui pengaruh bersamasama antara variabel independen terhadap variabel dependen. Pengujian F dilakukan dengan membandingkan $\mathrm{F}$ hitung dengan $\mathrm{F}$ table. Jika $\mathrm{F}$ hitung lebih besar dari $\mathrm{F}$ tabel dengan tingkat kepercayan $95 \%$ atau (p-value $<0,05$ ), maka Ha diterima yang artinya variabel independen yang diuji secara bersama-sama mempunyai pengaruh terhadap variabel dependen. Uji statistik F pada dasarnya menunjukkan apakah semua variabel bebas yang dimasukkan dalam model mempunyai pengaruh secara bersama-sama terhadap variabel terkait (dependent).

4. Analisis Data dan Pembahasan

4.1. Analisis Data

4.1.1. Uji Validitas dan Uji Reliabilitas

a. Uji Validitas

Dalam pengujian validitas ini menggunakan taraf signifikan 0,05 dengan $\mathrm{N}=100$ menghasilkan $\mathrm{R}$ tabel sebesar 0,195 . Dikatakan valid apabila nilai $\mathrm{R}$ hitung $>\mathrm{R}$ tabel. Untuk lebih jelasnya dapat dilihat seperti tabel dibawah ini. 
Tabel 1. Uji Validitas

\begin{tabular}{|c|c|c|c|}
\hline Indikator & R hitung & R table & Keterangan \\
\hline $\mathrm{X} 1.1$ & 0,673 & 0,195 & Valid \\
\hline $\mathrm{X} 1.2$ & 0,783 & 0,195 & Valid \\
\hline $\mathrm{X} 1.3$ & 0,788 & 0,195 & Valid \\
\hline $\mathrm{X} 2.1$ & 0,453 & 0,195 & Valid \\
\hline $\mathrm{X} 2.2$ & 0,696 & 0,195 & Valid \\
\hline $\mathrm{X} 2.3$ & 0.750 & 0,195 & Valid \\
\hline $\mathrm{X} 2.4$ & 0,555 & 0,195 & Valid \\
\hline $\mathrm{X} 2.5$ & 0,572 & 0,195 & Valid \\
\hline $\mathrm{Y} .1$ & 0,764 & 0,195 & Valid \\
\hline Y.2 & 0,828 & 0,195 & Valid \\
\hline Y.3 & 0,754 & 0,195 & Valid \\
\hline
\end{tabular}

Berdasarkan Tabel 1 di atas, diperoleh nilai R dari setiap item pertanyaan lebih besar dari $\mathrm{R}$ table sehingga dapat disimpulkan bahwa item-item pertanyaan sudah valid.

b. Uji Reliabilitas

Pada pengujian Reliabilitas ini, untuk standar reliabilitasnya dikatakan reliabel apabila nilai krombak alfa >0,60 maka dapat dilihat seperti tabel di bawah ini :

Tabel 2. Uji Reliabilitas

\begin{tabular}{|l|c|c|c|}
\hline Variabel dan Indikator & Cronbach's Alpha & Standar Reliabilitas & Keterangan \\
\hline Inovasi (X1) & 0,802 & $>0,60$ & Reliabel \\
\hline Kreativitas (X2) & 0.740 & $>0,60$ & Reliabel \\
\hline Kepuasan Konsumen (Y) & 0,818 & $>0,60$ & Reliabel \\
\hline
\end{tabular}

Berdasarkan Tabel 2 di atas, diperoleh nilai Cronbach's Alpha dari setiap variabel lebih besar dari 0,60 sehingga dapat disimpulkan bahwa data sudah reliable atau konstan.

\subsubsection{Uji Asumsi Klasik}

a. Uji Normalitas

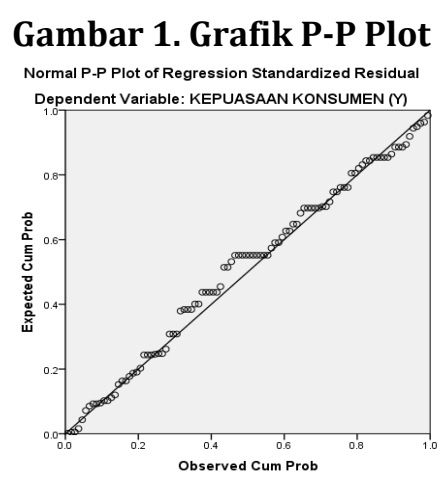

Sumber: Output SPSS Versi 21

Grafik diatas mempertegas bahwa model regresi yang diperoleh berdistribusi normal, dimana sebaran data berada disekitar garis diagonal. 
b. Uji Multikolinearitas

Tabel 3. Uji Multikolinearitas

\begin{tabular}{|c|c|c|c|c|c|}
\hline \multirow[t]{2}{*}{ Model } & \multicolumn{2}{|c|}{$\begin{array}{c}\text { Unstandardized } \\
\text { Coefficients }\end{array}$} & \multirow{2}{*}{$\begin{array}{c}\begin{array}{c}\text { Standardized } \\
\text { Coefficients }\end{array} \\
\text { Beta }\end{array}$} & \multicolumn{2}{|c|}{ Collinearity Statistics } \\
\hline & $\mathrm{B}$ & $\begin{array}{l}\text { Std. } \\
\text { Error }\end{array}$ & & Tolerance & VIF \\
\hline (Constant) & 5.056 & 1.550 & & & \\
\hline 1 INOVASI (X1) & .337 & .095 & .328 & .895 & 1.118 \\
\hline KREATIVITAS (X2) & .190 & .060 & .294 & .895 & 1.118 \\
\hline
\end{tabular}

a. Dependent Variable: KEPUASAAN KONSUMEN (Y)

Sumber: Output SPSS Versi 21

Berdasarkan Tabel 3 diatas, diperoleh nilai tolerance 0,895 > 0,100 dan nilai VIF $1.118<$ 10,00 sehingga dapat disimpulkan tidak terdapat gejala multikolinearitas.

c. Uji Heteroskedastisitas

\section{Gambar 2. Scatterplot}

Scatterplot

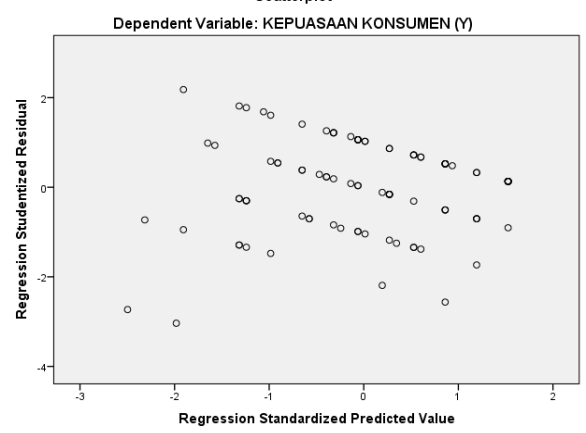

Sumber: Output SPSS Versi 21

Berdasarkan Gambar 2 di atas, dapat dilihat tidak ada pola-pola yang jelas (gergelombang, melebar kemudian menyempit) pada gambar scatterplot, serta titik-titik menyebar diatas dan dibawah angka 0 pada sumbu Y sehingga dapat disimpulkan tidak terjadi gejala heteroskedastisitas.

d. Uji Autokorelasi

Tabel 4. Uji Autokorelasi

\begin{tabular}{|l|l|l|l|l|l|}
\hline Model & $\mathrm{R}$ & R Square & $\begin{array}{l}\text { Adjusted R } \\
\text { Square }\end{array}$ & $\begin{array}{l}\text { Std. Error of } \\
\text { the Estimate }\end{array}$ & Durbin-Watson \\
\hline 1 & $.507 \mathrm{a}$ & .257 & .242 & .982 & 2.057 \\
\hline
\end{tabular}

a. Predictors: (Constant), KREATIVITAS (X2), INOVASI (X1)

b. Dependent Variable: KEPUASAAN KONSUMEN (Y)

Sumber: Output SPSS Versi 21

Berdasarkan Tabel 4 diatas, diperoleh nilai dw sebesar 2,057 sehingga diperoleh nilai du pada distribusi nilai tabel durbin watson adalah sebesar 1,715. Nilai k (2) dan N (100) dengan signifikansi 5\%. Nilai du (1.715) < Durbin Watson (2.057) < 4-du (2.285) artinya tidak gejala autokolerasi. 


\subsubsection{Regresi Linier Berganda}

Tabel 5. Regresi Linier Berganda

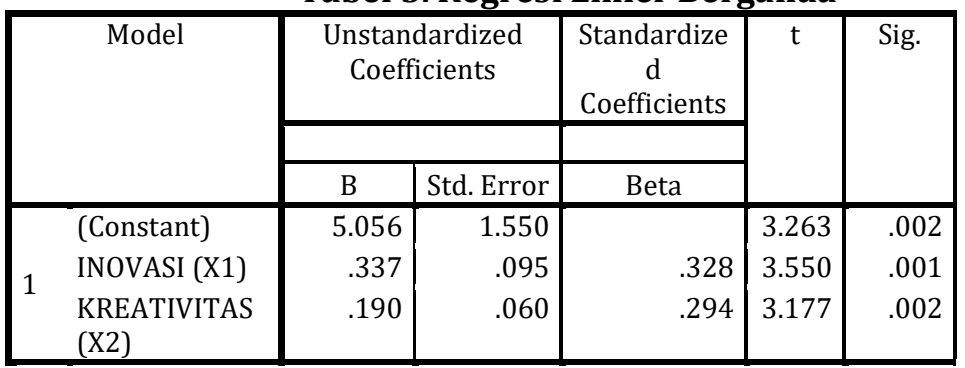

a. Dependent Variable: KEPUASAAN KONSUMEN (Y)

Sumber: Output SPSS Versi 21 berikut:

Berdasarkan Tabel 5 diatas, diperolehPersamaan regresi linier berganda adalah sebagai

Artinya:

$$
Y=5.056+0,337 X_{1}+0,190 X_{2}
$$

a. a (konstanta) $=5.056$ artinya jika Inovasi dan Kreativitas konstan atau sama dengan nol maka Kepuasan Konsumen pada UKM Dina Kelurahan Ntobo akan naik sebesar 5.056.

b. b1 = 0,337 artinya jika Inovasi naik sebesar $1 \%$ dimana Kreativitas konstan maka Kepuasan KonsumenUKM Dina Kelurahan Ntoboakan naik sebesar 0.337.

c. $\mathrm{b} 2=0,190$ artinya jika Kreativitasnaik sebesar $1 \%$ dimana Inovasi konstan maka Kepuasan Konsumen pada UKM Dina Kelurahan Ntobo akan naik sebesar 0,190.

Hal ini menujukan bahwa variabel Inovasi dan Krativitas memiliki pengaruh terhadap kepuasan konsumen pada UKM Dina Kelurahan Ntobo.

\subsubsection{Koefisien Korelasi}

Tabel 6. Koefisien Korelasi

\begin{tabular}{|l|r|r|r|r|r|}
\hline Model & \multicolumn{1}{|c|}{$\mathrm{R}$} & $\begin{array}{c}\mathrm{R} \\
\text { Square }\end{array}$ & $\begin{array}{c}\text { Adjusted } \\
\text { R Square }\end{array}$ & $\begin{array}{c}\text { Std. Error of } \\
\text { the Estimate }\end{array}$ & $\begin{array}{c}\text { Durbin- } \\
\text { Watson }\end{array}$ \\
\hline 1 & $.507 \mathrm{a}$ & .257 & .242 & .982 & 2.057 \\
\hline
\end{tabular}

a. Predictors: (Constant), KREATIVITAS (X2), INOVASI (X1)

b. Dependent Variable: KEPUASAAN KONSUMEN (Y)

Sumber: Output SPSS Versi 21

Berdasarkan Tabel 6 diatas,terlihat koefisien korelasi sebesar 0,507 atau $\mathrm{r}=0,507$ angka tersebut menunjukkan korelasi yang sedang karena berada pada rentang 0,40 -0,599.

\subsubsection{Koefisien Determinasi}

Berdasarkan Tabel 6 diatas, diperoleh nilai koefisien determinasi linier berganda yaitu sebesar 0,257 atau $25,70 \%$. Artinya pengaruh Inovasi $\left(\mathrm{X}_{1}\right)$ dan Kreativitas $\left(\mathrm{X}_{2}\right)$ terhadap Kepuasan Konsumenpada UKM Dina Kelurahan Ntobo yaitu sebesar 25,70\% sedangkan sisanya $74,30 \%$ dipengaruhi oleh faktor-faktor lain yang tidak diteliti dalam penelitian.

\subsubsection{Uji t ( Uji Parsial)}

Tabel 7. Uji T

\begin{tabular}{|l|r|r|r|r|r|}
\hline \multirow{2}{*}{ Model } & \multicolumn{2}{|c|}{$\begin{array}{c}\text { Unstandardized } \\
\text { Coefficients }\end{array}$} & $\begin{array}{c}\text { Standardized } \\
\text { Coefficients }\end{array}$ & \multirow{2}{*}{$\mathrm{t}$} & \multirow{2}{*}{ Sig. } \\
\cline { 2 - 4 } & \multicolumn{1}{|c|}{ B } & Std. Error & \multicolumn{1}{c|}{ Beta } & & \\
\hline (Constant) & 5.056 & 1.550 & & 3.263 & .002 \\
1 INOVASI (X1) & .337 & .095 & .328 & 3.550 & .001 \\
KREATIVITAS (X2) & .190 & .060 & .294 & 3.177 & .002 \\
\hline
\end{tabular}

a. Dependent Variable: KEPUASAAN KONSUMEN (Y)

Sumber: Output SPSS Versi 21 
a. Pengaruh Inovasi Terhadap Kepuasan Konsumen

Berdasarkan Tabel 8 diatas, diperoleh Nilai $t_{\text {hitung }}$ untuk variable Inovasi (X1) adalah sebesar 3.550 yang artinya Inovasi berpengaruh terhadap Kepuasan Konsumen. Pengujian dua arah alpha $(\alpha) / 2=0,05 / 2=0,025$ dan derajat bebas $(\mathrm{dk})=\mathrm{n}-\mathrm{k}-1$ dengan $\mathrm{k}$ adalah jumlah variabel bebas dan terikat, maka $(\mathrm{dk})=100-2-1=97$. Sehingga diperoleh nilai $t_{\text {tabel }}$ sebesar 1.984. Dan tingkat signifikan (Sig) > dari 0,05 yaitu Sig.0,001< 0,05 artinya ada pengaruh yang signifikan antara Inovasi (X1) terhadap Kepuasan Konsumen (Y) pada UKM Dina Kelurahan Ntobo (H1 diterima).

b. Pengaruh Kreativitas Terhadap Kepuasan Konsumen

Berdasarkan Tabel 8 diatas, diperoleh nilai thitung untuk variable Kreativitas (X2) adalah sebesar3.177 yang artinya Kreativitas berpengaruh terhadap Kepuasan Konsumen. Pengujian dua arah alpha $(\alpha) / 2=0,05 / 2=0,025$ dan derajat bebas $(\mathrm{dk})=\mathrm{n}-\mathrm{k}-1$ dengan $\mathrm{k}$ adalah jumlah variabel bebas dan terikat, maka $(\mathrm{dk})=100-2-1=97$. Sehingga diperoleh nilai $t_{\text {tabel }}$ sebesar 1.984. Dan tingkat signifikan (Sig) $>$ dari 0,05 yaitu Sig.0,002<0,05 artinya ada pengaruh yang signifikan antara Kreativitas (X2) terhadap Kepuasan Konsumen (Y) pada UKM Dina Kelurahan Ntobo (H2 diterima).

\subsubsection{Uji F ( Uji Simultan)}

Tabel 9. Uji F

\begin{tabular}{|c|c|c|c|c|c|}
\hline Model & $\begin{array}{l}\text { Sum of } \\
\text { Squares }\end{array}$ & Df & $\begin{array}{c}\text { Mean } \\
\text { Square }\end{array}$ & $\mathrm{F}$ & Sig. \\
\hline Regression & 32.382 & 2 & 16.191 & 16.776 & $.000^{\mathrm{b}}$ \\
\hline Residual & 93.618 & 97 & .965 & & \\
\hline Total & 126.000 & 99 & & & \\
\hline
\end{tabular}

a. Dependent Variable: KEPUASAAN KONSUMEN (Y)

b. Predictors: (Constant), KREATIVITAS (X2), INOVASI (X1)

Sumber: Output SPSS Versi 21

Berdasarkan Tabel 9 di atas, diperoleh nilai $\mathrm{F}$ hitung sebesar 16,776. Adapun rumus untuk mencari nilai $\mathrm{F}$ tabel adalah sebagai berikut $\mathrm{df} 1=\mathrm{k}-1$ dan $\mathrm{df} 2=\mathrm{n}-\mathrm{k}$. jadi $\mathrm{df} 1=2-1=2$, dan df2 $=100-2=98$. Dari rumus tersebut di dapatkan nilai $\mathrm{F}$ tabel sebesar 3,09, jadi nilai $\mathrm{F}$ hitung $>$ F tabel yang berarti H3 diterima dengan nilai signifikan sebesar $0,000<0.05$. Jadi, secara bersama-sama atau secara simultan bahwa variabel Inovasi (X1) dan Kreativitas (X2) secara simultan berpengaruh terhadap Kepuasan Konsumen (Y) pada UKM Dina Kelurahan Ntobo (H3 diterima).

\subsection{Pembahasan}

\subsubsection{Pengaruh Inovasi Terhadap Kepuasan Konsumen}

Pada penelitian ini Inovasi berpengaruh terhadap Kepuasan konsumen pada Ukm Dina Kelurahan Ntobo, hal ini ditunjukan dari Tabel 8 diatas, dimana diperoleh Nilai thitung untuk variable Inovasi (X1) adalah sebesar 3.550 yang artinya Inovasi berpengaruh terhadap Kepuasan Konsumen. Pengujian dua arah alpha $(\alpha) / 2=0,05 / 2=0,025$ dan derajat bebas $(\mathrm{dk})=$ $\mathrm{n}-\mathrm{k}-1$ dengan $\mathrm{k}$ adalah jumlah variabel bebas dan terikat, maka $(\mathrm{dk})=100-2-1=97$. Sehingga diperoleh nilai tabel sebesar 1.984. Dan tingkat signifikan (Sig) > dari 0,05 yaitu Sig.0,001<0,05 artinya pengujian Hipotesis 1 DITERIMA, Hal ini sejalan dengan penelitian yang dilakukan oleh Sukarmen (2013) bahwa inovasi berpengaruh signifikan terhadap kepuasan konsumen. 


\subsubsection{Pengaruh Kreativitas Terhadap Kepuasan Konsumen}

Dalam penelitian ini kreativitas berpengaruh signifikan terhadap kepuasan konsumen pada Ukm Dina Kelurahan Ntobo, hal ini ditunjukkan dariTabel 8 diatas, diperoleh nilai $t_{\text {hitung }}$ untuk variable Kreativitas (X2) adalah sebesar 3.177 yang artinya Kreativitas berpengaruh terhadap Kepuasan Konsumen. Pengujian dua arah alpha $(\alpha) / 2=0,05 / 2=0,025$ dan derajat bebas $(\mathrm{dk})=\mathrm{n}-\mathrm{k}-1$ dengan $\mathrm{k}$ adalah jumlah variabel bebas dan terikat, maka $(\mathrm{dk})=100-2-1$ $=97$. Sehingga diperoleh nilai tabel sebesar 1.984. Dan tingkat signifikan (Sig) $>$ dari 0,05 yaitu Sig.0,002<0,05 artinya pengujian Hipotesis 2 DITERIMA, Hal ini sejalan dengan penelitian yang dilakukan oleh Munthe (2019) bahwa kreativitas secara parsial berpengaruh signifikan terhadap kepuasan konsumen.

\subsubsection{Pengaruh Inovasi Dan Kreatifitas Terhadap Kepuasan Konsumen}

Dari hasil penelitian ini inovasi dan kreativitas berpengaruh terhadap kepuasan konsumen pada Ukm Dina Kelurahan Ntobo, hal ini ditunjukkan berdasarkan Tabel 9 diatas, diperoleh nilai $F_{\text {hitung }}$ sebesar 16,776 . Adapun rumus untuk mencari nilai $F_{\text {tabel }}$ adalah sebagai berikut df1 $=\mathrm{k}-1$ dan df2 = n-k. jadi df1 $=2-1=2$, dan df2 $=100-2=98$. Dari rumus tersebut di dapatkan nilai $\mathrm{f}_{\text {tabel }}$ sebesar 3,09, jadi nilai $\mathrm{F}_{\text {hitung }}>\mathrm{F}_{\text {tabel }}$ yang berarti hipotesis 3 DITERIMA dengan nilai signifikan sebesar $0,000<0.05$. Jadi, secara bersama-sama atau secara simultan bahwa variabel Inovasi dan Kreativitas Secara Simultan Berpengaruh Terhadap Kepuasan Konsumen pada UKM Dina Kelurahan Ntobo, Hal ini sejalan dengan penelitian yang dilakukan oleh Aditi dan Hermansyur (2017) bahwa inovasi dan kreativitas berpengaruh signifikan secara simultan terhadap kepuasan konsumen.

\section{Kesimpulan dan Rekomendasi}

\subsection{Kesimpulan}

a. Inovasi secara parsial berpengaruh signifikan terhadap kepuasan konsumen. Hal ini dikarenakan dengan semakin tinggi dalam melakukan inovasi produk, maka semakin tinggi kepuasan konsumen.

b. Kreativitas secara parsial berpengaruh signifikan terhadap kepuasan konsumen. Hal ini dikarenakan semakin tinggi tingkat kreativitas, maka kepuasan konsumen pun akan meningkat.

c. Inovasi dan kreativitas secara simultan berpengaruh signifikan terhadap kepuasan konsumen. Hal ini juga menunjukkan bahwa tinggi rendah nya suatu inovasi dan kreativitas memiliki pengaruh terhadap kepuasan konsumen.

\section{2. $\quad$ Rekomendasi}

Bagi peneliti selanjutnya disarankan penambahan variabel penelitian agar menjadikan suatu penelitian lebih baik lagi sehingga hasilnya dapat diberagam. Penambahan variabel baru seperti promosi, harga dan desain dapat membuat penelitian selanjutnya lebih menarik dan dapat menjelaskan fenomena tentang kepuasan konsumen dengan lebih komprehensif.

\section{Referensi}

Abdullah, F. (2015). Pengaruh Kreativitas Dan Inovasi Terhadap Keberhasilan Usaha Pada Usaha Tauko Medan.

Aditi, B. (2018). Pengaruh Inovasi Dan Kreativitas Terhadap Kepuasan Konsumen Pada Umkm Di Kota Medan. Jumant, 7(1), 1-9.

Ardani, S. I., \& Wati, R. D. S. (2019). Peran Kepuasan Pelanggan Dalam Memediasi Pengaruh Inovasi Produk Terhadap Loyalitas Pelanggan (Studi Pada Konsumen Warunk Upnormal). E-Jurnal Manajemen, 8(12), 7177-7195.

E., V. F., \& Mukaram, M. (2020). Pengaruh Inovasi Produk Terhadap Kepuasan Konsumen (Studi pada Road Cafe Steak \& Pasta Bandung. In: Prosiding IndustrialResearchWorkhshopand National Seminar, 11(1), 969-976. 
Ernawati, S., \& Kurniati, U. (2020). Pengaruh Kreatifitas Produk Dan Inovasi Produk Terhadap Kepuasan Konsumen Di Steak House Noodles. Jurnal Ekonomi, Manajemen Dan Akuntansi, 4(1), 112-119.

Fandy, T. (2015). Strategi Pemasaran Jasa. CV. Andi.

Ferninand, A. (2014). Metode Penelitian Manajemen (5th ed.). Badan penerbit Universitas Diponegoro.

Ghozali, I. (2013). Aplikasi Analisis Multivariate dengan Program IBM SPSS 21 Update PLS Regresi. Badan penerbit Universitas Diponegoro.

Hadiyanti, E. (2011). Kreativitas dan Inovasi berpengaruh terhadap Kewirausahaan Usaha Kecil. Jurnal Manajemen Dan Kewirausahaan, Vol. 13 No, 8-16.

Kotler, P., \& Keller, K. L. (2016). Prinsip-Prinsip Pemasaran. Erlangga.

Kotler, Phillip. (2005). Manajer Pemasaran , Manajemen Pemasaran (1st ed.). Prenhallindo.

Mulyadi, W., E., T. R., \& Widjaja, A. E. (2016). Pengaruh Inovasi, Kreativitas, Dan Kepuasan Konsumen Terhadap Keunggulan Kompetitif : Sebuah Studi Kasus. Informasi In Prosiding Seminar Nasional InovasiDan Teknologi, 1610-1615.

N., R. M. (2019). Pengaruh Kreativitas Dan Kualitas Pelayanan Terhadap Kepuasan Peserta Bpjs Ketenagakerjaan Cabang Pematangsiantar. JEEKP Uurnal Ekonomi, Keuangan Dan Kebijakan Publik), 1(1), 31-39.

Sentra Kerajinan Bambu Mangkubumi Kota Tasikmalaya. (n.d.). Jurnal Ilmiah Adbis Administrasi Bisnis, 3(2), 19-34.

Sudaryanto, R., \& R. R. Wijayanti. (2014). . : Pusat Kebijakan Ekonomi BKF Jakarta Kemenkeu.

Sugiyono. (2016). Metode Penelitian Kuantitatif, Kualitatif Dan R\&D. PT. Alfabet.

Sukarmen, P., A. R, S., \& Wulandari, D. (2015). Analisis Pengaruh Inovasi Produk Terhadap Kepuasan Konsumen Dengan Keunggulan Bersaing Sebagai Variabel Intervening Pada Produk Gula Pasir Sebelas (Gupalas) Pabrik Gula Sembro Ptp Nusantara Xi (Persero). Jurnal Ekonomi Akuntansi Dan Manajemen, 12(2), 64-79.

Suryana, \& Dkk. (2003). Kewirausahaan: pedoman praktis, kiat dan proses menuju sukses. Salemba Empat.

W., N. M. K. (2019). Pengaruh Inovasi Produk Terhadap Niat Pembelian Ulang Dimediasi Oleh Kepuasan Konsumen. E-Jurnal Manajemen, 8(8), 4983-5006.

Zimmerer, T. W., \& Scarborough, N. M. (2008). Kewirausahaan dan Manajemen Usaha kecil. Salemba Empat. 